\title{
On Higher Education
}

Transformation

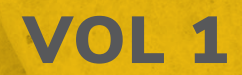

\section{SCHOLARLY \\ ENGAGEMENT AND \\ DECOLONISATION}

Editors:

M Crul, L Dick, H Ghorashi \& A Valenzuela Jr

Views from South Africa,

The Netherlands and the United States 


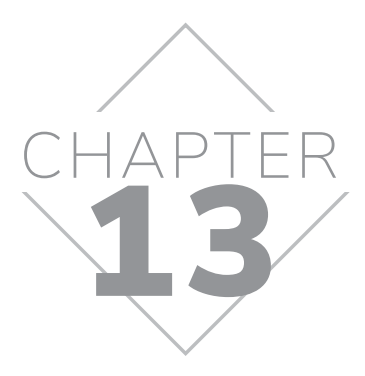

\title{
College choice
}

\section{Supporting Latinx youth visions of higher education}

\author{
Isabel Coatlicue Durón
}

\section{ABSTRACT}

To have a conversation on the diversity in higher education, requires that we examine the educational pipeline even before students are accepted into institutions of higher education. For Latinx students in the United States, acceptance and entrance into institutions of higher education continues to be a major challenge. Research demonstrates that Latinx students in California and in the country experience an educational equity gap throughout the educational pipeline that diminishes the opportunities to obtain a bachelor's degree or higher (Sólorzano, Villalpando \& Oseguera, 2005). While much education research considers the policies and challenges that Latinx students - both documented and undocumented - face, this article considers how one non-profit organisation in the Los Angeles area has aided Latinx students in achieving their dreams of higher education, as well as challenges that the youth and organisation face in continuing this work.

Keywords: college-going; college-choice; Latina/o; Latinx educational pipeline; precarity; afterschool programs; nonprofit; not-for-profit 


\section{SCHOLARLY ENGAGEMENT AND DECOLONISATION}

\section{AUTHOR'S NOTE:}

While critically engaging decolonisation is an important site of inquiry particularly for academia, this chapter in particular does not purport to engage in any meaningful way with decolonisation. Engaging critically in decolonisation from a US perspective requires not only that indigenous (i.e. Native American) voices and ethos are centered, but must begin from the premise that it be "accountable to Indigenous sovereignty and futurity" (Tuck \& Yang, 2012:35). Educational and Critical Ethnic Studies scholars Eve Tuck (Unangax) and $\mathrm{K}$. Wayne Yang argue that decolonisation "specifically requires the repatriation of Indigenous land and life" (26). I do not want to suggest that to critically engage decolonisation is of no interest to me or should only be left up to indigenous people, but rather to be engaged in a different scholarly pursuit and to mislabel this work - whether derived from a social justice frame or not - risks reducing decolonisation to a metaphor, as Tuck and Yang argue. In academia, reducing decolonisation to a metaphor not only supplants indigenous voices with others that may be marginalised, but to do so participates in indigenous erasures, reflects a continuation of colonial violence, and evades any critical engagement with both colonisation and decolonisation. Instead, in this Chapter, I examine the challenges that Latinx students and the non-profits that serve them face in trying to get them into institutions of higher education.

Tuck, E. \& Yang, K. W. (2012). Decolonization is not a metaphor. Decolonization: Indigeneity, Education \& Society, 1(1): 1-40.

\section{INTRODUCTION}

Although the Westside in Los Angeles usually conjures images of the beach, wealth, whiteness and luxury, I center this study on the primarily Mexicanorigin, low-income, working class families and youth served by the Family Leadership Center (FLC), a community-based non-profit organisation. Empire Street, where the center is located, contrasts to the images of privilege usually associated with the Westside. These families struggle with financial insecurity, illegality, educational opportunities and gangs. A set of federal urban housing projects are located near the FLC. However, FLC and its Urban Youth Program (UYP), which serves youth 13-18 years of age, appear to be a bright spot for many of these families, offering hope for opportunities that may improve their educational outcomes and life chances. 
The research presented in this chapter focuses on analysing how nonprofit organisations support Latin $x^{1}$ dreams of higher education. In order to understand the significance of this work, I consider the challenges that Latinx students face as barriers to institutions of higher education. Finally, I not only consider the work that the organisation does, but also consider organisational challenges that threaten its existence. Without the organisation, students may be left without important structures that support their dreams of higher education.

I begin by providing a framework for understanding how Latinx students are pushed out and locked out along the educational pipeline. I then provide a more detailed portrait and philosophy of the center, its youth and the youth programmeitself.I consider how the centercreates a collegechoiceenvironment and consider how this is distinct from a 'college-going' environment. I make connections between directly supporting youth's understanding of the college-going process, as well as empowering experiences they reflect on that may serve as powerful motivators for persisting on a college track. I argue that it is imperative to consider not only how an organisation does this work to support youth but what it takes to maintain this work.

\section{PUSHED OUT AND LOCKED OUT - BARRIERS TO HIGHER EDUCATION}

Latinx youth face many barriers to enrolling in institutions of higher education. These barriers include being pushed out from the schooling process, lack of knowledge and preparation of the college enrolment process, and financial insecurity and burdensome costs of enrolling into institutions of higher education (Burciaga, Pérez Huber \& Solórzano, 2010; Valenzuela, 1999). Even as college enrolment rates and educational attainment have increased for Latinos in the US, a persistent education equity gap remains with Latinos lagging behind non-Latino whites (Sólorzano, Villalpando \& Oseguera, 2005; Pérez Huber, Vélez \& Solórzano, 2014). In policy report, Pérez Huber et al. (2014)

1 I use the term Latinx as a pan-ethnic label to reference people of Latin American origin. This term is a discursive move towards gender inclusivity and gender fluidity of what is often referred to as the Latina/o population. In the US, government documents often categorise this diverse ethnic population as Hispanic or Latino. In these cases, I use the term Latinx. For more information on how the term Latinx has gained significant traction both publicly and academically, see Salinas and Lozano (2017) and Ramirez and Bley (2016). 


\section{SCHOLARLY ENGAGEMENT AND DECOLONISATION}

recognised that even as approximately $60 \%$ of Latinx students became high school graduates in California in 2012, they represented only $13 \%$ of adults who earned a high school diploma in California. This is below the $30 \%$ Latinx population state-wide. While white adults in California were overrepresented in terms of the percent of their population at all levels of educational attainment. This points to an important and persistent gap in educational attainment, one that Pérez Huber et al. (2014) define as an educational equity gap.

A report prepared by the California Senate Office of Research (CA SOR) for the Latino Legislative Caucus also demonstrates that even though some students graduate from high school, they are not prepared for college level courses. Based on state-wide standardised test data, only $50 \%$ of Latinx students met or exceeded English-language arts standards and only 20\% of Latinx students met or exceeded Mathematical standards. In comparison, $69 \%$ and $52 \%$ of non-Latino students scored at or above English-language arts and Mathematical standards respectively. $85 \%$ of Latinx students enrolled at community colleges "are placed in precollege-level courses, taking at least one developmental course in math, English, or both" (CA SOR, 2017:9). The educational equity gap has been growing and continues to not only persist but increase through the rest of the educational pipeline (Pérez Huber et al., 2014; Pérez Huber, Malagón, Ramirez, Camargo Gonzalez, Jimenez \& Vélez, 2015). This is particularly troubling as the Latinx student population in California has continued to increase - increasing at a much faster rate than other ethnic groups in the state of California (CA SOR, 2017).

The gap in educational attainment is not for lack of motivation or interest in education. Latinx communities are more likely to see higher education as an important economic milestone. A Pew Hispanic Center (Lopez, 2009) survey found $88 \%$ Latinxs agreed that a college degree is important for getting ahead in life, more so than the general public (74\%) (Lopez, 2009). Additionally, 77\% of Latinx youth reported that their parents thought that after completing high school the most important thing was attending college. Education was also reported as the most important issue for Latinx voters in the 2016 presidential election, coming above the economy and immigration though these were also top-rated issues (Lopez, Gonzalez-Barrera, Krogstad \& Lopéz, 2016). 
Though the educational equity gap decreases over the course of the schooling process, for Latinx students (CA SOR, 2017), "the underrepresentation and underachievement of Latinx students at each point in the pipeline might be better explained by examining the educational conditions these students encounter at their preschool, elementary and secondary school 'headwaters'” (Burciaga et al., 2010:425). For example, Latinx children often do not receive preschool education because of the lack of information or the unaffordability of these programmes (Burciaga et al., 2010). Additionally, Latinx families are more likely to be struggling with poverty and unable to afford additional educational supports such as tutoring or educational enrichment programs than wealthier families can. In California, for example, poverty statistics demonstrate that although $10 \%$ of whites live in poverty, 19\% of Latinos live in poverty; Latino rates of poverty are close to double those of whites (Kaiser Family Foundation, 2007). In Los Angeles, Mexican-ethnic households' wealth represents only $1 \%$ of what white households have, with a median net worth of only $\$ 3,500$. White households in Los Angeles have a median net worth of $\$ 355,000$ (De La Cruz-Viesca, Chen, Ong, Hamilton \& Darity, 2016). The income and wealth disparities of Latinx households demonstrate significant obstacles. However, by only examining these obstacles it can be easy to miss the cultural wealth that Latinx communities can and have drawn on.

Additionally, research demonstrates that Latinx youth are often pushed out from schools. There is a long history of racism that Latinx youth have experienced in the US. Similar to African Americans, in the early part of the $20^{\text {th }}$ century, Latinx students were segregated from white students during their schooling process, experiencing separate and unequal schools (San Miguel \& Donato, 2010). As a precursor to the court case Board vs. Board of Education, which desegregated public education on a national level, the 1964 California state ruling in Mendez vs. Westminster recognised that the segregated schooling of children of Mexican descent was inherently unequal (San Miguel \& Donato, 2010; Strum, 2010). Though segregation in public schools was legally prohibited in the 1940s, many Mexican and Mexican American children continued to experience underfunded and under-resourced schools (Burciaga et al., 2010). In addition to this, Latinx students experienced administrative bias and a subtractive schooling process that demeaned and devalued the culture and intellectual capability of Latinx students (Valenzuela, 1999; Burciaga et al., 2010; San Miguel \& Donato, 2010). 


\section{SCHOLARLY ENGAGEMENT AND DECOLONISATION}

Based on research of Mexican and Mexican American youth in Texas, Angela Valenzuela's (1999) research describes a subtractive schooling process that demeans and devalues Mexican and Mexican American youth. Even though teachers at this high school viewed students as the main impediment to their own education, Valenzuela's research, with the youth themselves, demonstrates that the type of education Latinx students received was not based on respect. Youth recognised when teachers did not care and became disinterested in participating in the schooling process. The disengagement of Latinx youth is therefore a product of the type of schooling they receive rather than a refusal of education in general.

More recent research has continued to make connections between the ways in which schools are increasingly connected to the criminal justice system. Often referred to as the 'school-to-prison' pipeline, this research reveals the ways in which increased policing and zero-tolerance policies criminalise youth and often create a connection to the prison system (Noguera, 2003; Wald \& Losen, 2003; Kwon, 2006; Kim, Losen \& Hewitt, 2010; Freeman et al., 2013). Though white students also experience some of these policies, research demonstrates that students of colour have more encounters with police through these schoolbased policies (Freeman et al., 2013). A report published by the Community Rights Campaign (Freeman et al., 2013) found that in the Los Angeles Unified School District (LAUSD) truancy tickets and daytime curfew violations were the number one reason for which students were referred by police into the juvenile justice system. By 2013, the total number of truancy tickets had significantly reduced, however "even as overall numbers have come down, the intense racialisation of tickets and arrests has worsened. A Latino student continues to be more than twice as likely to be ticketed and arrested at school than a white student" (Freeman et al., 2013:6). Black students were also more likely to be targeted (Freeman et al., 2013). As police have become a consistent presence on school campuses, schools have served as sites where students, particularly minority and racialised youth, are introduced to the criminal justice system impeding their access to living full lives much less attending institutions of higher education (Kim et al., 2010; Freeman et al., 2013).

Even when not in schools, Latinx youth may experience overpolicing in their own communities. While educational budgets, including funding for youth programmes, have been severely cut both nationally and in California, funding 
for criminal institutions has not decreased. While California ranks number 49 in education spending per person in the US, it is simultaneously the state with the highest prison spending per person in the US (Freeman et al., 2013). Victor Rios' (2011) research of African American and Latino low-income youth not only interrogates the 'overpolicing' and criminalisation of youth, but he also reveals that "the state had not abandoned the poor; it had reorganised itself, placing priority on its punitive institutions, such as police, and embedding crime-control discourses and practices into welfare institutions such as school" (p.xiii). Even though Latinx and African American youth had not engaged in any criminal activity, their dress and behaviours are criminalised. Latinx communities are also criminalised in the context of their legal status.

Latinx mixed status (i.e. documented and undocumented) families are criminalised through both the production of illegality and racialisation. Racialisation and illegality diminish not only the humanity of Latinx communities, but also diminishes opportunities (Lipsitz, 1998, 2011; Menjívar, 2006; De Genova, 2009; Hosang, LaBennet \& Pulido, 2012; Molina, 2013; Omi \& Winant, 2015). For undocumented individuals, accessing jobs, education, health care and a multitude of other social services can be extremely difficult. Undocumented individuals are not entitled to many basic services and in the US employment is not guaranteed; even when employment is attained, undocumented workers often encounter exploitation (Abrego, 2014). Undocumented children and youth have a legal right to $\mathrm{K}-12^{2}$ education in the U.S. However, higher education and financial aid at the college level are not guaranteed. The risk and fear of deportation is also a substantial weight. "Undocumented immigrants and their loved ones must grapple with the fear of deportation at every turn; this is a heavy burden that millions carry" (Abrego, 2014:7). For youth who are undocumented or in mixed status families, both deportation and the fear of deportation can impact the emotional well-being of students making it difficult for them to concentrate in school.

Even in the midst of such odds, undocumented activists and allies have been able to make important and invaluable gains for undocumented individuals and their families. In California, their efforts resulted in the passage of the California DREAM (Development, Relief, and Education for Alien Minors)

2 K-12 education refers to Kindergarten to $12^{\text {th }}$ grade. Children usually enter kindergarten at 5 or 6 years old and $12^{\text {th }}$ grade is the final year of high school. 


\section{SCHOLARLY ENGAGEMENT AND DECOLONISATION}

Act. Through the California DREAM Act, undocumented students were finally eligible for state-funded financial aid at institutions of higher education. Even before the California DREAM Act passed, activists created systems to support undocumented students in institutions of higher education throughout the state (UCLA Center for Labor Research and Education, 2008). The immigrant rights movement also pressured President Obama into authorising the Deferred Action for Childhood Arrivals (DACA) in 2012. If undocumented youth meet certain eligibility requirements, DACA provides work authorisation, a temporary Social Security number, and blocks deportation (Gonzales, 2014; Terriquez \& Kwon, 2014). The ability to work legally in the US is an important gain that represents the opportunity for upward social mobility. Though DACA provides access to many more resources, it does not provide a path to citizenship. This leaves DACA recipients' in a liminal legal status (Menjívar, 2006). DACA recipients legal status has been further threatened under Trump's presidency. As of the writing of this piece, DACA recipients are awaiting the United States Supreme Court decision which will decide whether the programme will be rescinded.

There are many barriers that Latinx students face in attempting to access institutions of higher education. I have examined some of the socio-political factors including illegality, racialisation, criminalisation, and subtractive schooling. Even against these factors, non-profits and community-based organisations work to provide youth with opportunities. The FLC is one of these organisations. I examine the microsystem that this organisation creates to get Latinx youth into institutions of higher education.

\section{METHODOLOGY}

This study uses a case study method that seeks to answer the following questions:

1. What is the role of non-profit organisations in supporting Latinx students' dreams of accessing institutions of higher education?

2. What challenges do Latinx students face in schools and in their environment and how do non-profit organisations work to address and remedy these challenges that can deter students from accessing institutions of higher education?

3. What challenges do non-profit organisations face in this intermediary role? 
This research focuses on one non-profit organisation, the $\mathrm{FLC}^{3}$ in the greater Los Angeles area, that provides programmes for K-12 grade students. The bulk of theis research focuses on UYP, as well as the FLC programme intended for teenage youth. I conducted this research from June 2015-August 2016. In order to protect the identity of research participants and the organisation, I have utilised pseudonyms for the youth participants, UYP and FLC.

There are three main phases of the research. I began by examining organisational documents. The centre provided me with access to internal organisational documents that pointed to the history and philosophy of the centre and to UYP more specifically, including an organisational manual, photo albums, information provided on their website, UYP meeting notes, youth reflections written by participants about the programme and drafts of college application essays written from 2001-2011, internal survey results administered to parents and youth about the programme, and finally rosters that included demographic information for each youth enrolled in UYP from 2011-2014. I also collected and analysed census data and School Accountability Report Cards in order to develop a clearer portrait of the youths' environment. ${ }^{4}$

The second phase of data collection included participant observations of the UYP programme. From January 2017-June 2016, I attended weekly Friday leadership youth meetings. I worked to build trust with participants during these sessions. I also attended tutoring sessions held during the weekdays during which I would assist the youth with their homework. More than that, I attended monthly parent meetings, college information sessions, Science, Technology, Engineering, and Mathematics (STEM) sessions for youth, core leadership planning meetings, community meetings, and special events put together by FLC and/or the youth. I conducted informal interviews during these times to learn more about the youth, their families, as well as their thoughts about UYP and FLC. I wrote field notes to document these site visits.

The third and final phase of data collection consisted of one-on-one in-depth interviews. I interviewed five staff members, 12 current youth participants, and four alumni of the program. Staff members were selected based on their

3 FLC is a pseudonym for the organisation.

4 School Accountability Report Cards (SARC) provide official school test results and quantitative profiles of K-12 institutions. 


\section{SCHOLARLY ENGAGEMENT AND DECOLONISATION}

working knowledge of the program. Interviews with staff and current youth participants were held in empty offices at FLC. Interviews were audio-recorded, transcribed and coded using the program Dedoose. Interviews lasted between 30-90 minutes. All one-on-one interview participants were Latinx.

At least three of the staff members had also participated in FLC's services during their childhood. In selecting current youth participants to interview, I attempted to maintain a gendered balance of interviews between male and female participants. Exactly half of the participants were male and the other half were female. I also attempted to recruit participants who were in different grades of the programme in order to capture youth at different stages of their development and involvement within the programme. One participant was in his first year of college, three participants were in the last year of high school, one participant was in the $11^{\text {th }}$ grade, two participants were in $10^{\text {th }}$ grade, nine participants were in $9^{\text {th }}$ grade and three participants were in $8^{\text {th }}$ grade. Based on my observations, I attempted to gather youth with different levels of participation within the programme. Finally, in order to protect the privacy of former participants, FLC first reached out to alumni of UYP that they believed would be interested in participating. This required that the organisation had maintained contact information for these past participants. Past participants who had completed the youth programme at least five years earlier had been recruited in order to consider the trajectory of their lives since participating in FLC's programmes. Former UYP participants were in their late 20s or in their 30s.

Interviews with staff primarily focused on discerning their philosophy, analysis of student growth and the challenges of carrying out their vision of supporting youth. Interviews with current participants focused on understanding their environment including their perceptions of the community they lived in, the neighbourhood where FLC is located, family history and relationships, and identifying the ways in which FLC supported them and any additional support they received in developing educationally or personally. Interviews with former participants focused on their memories of FLC, their perception of how FLC helped them in their educational or personal trajectory, and their educational trajectory once graduating from high school. 


\section{FAMILY LEADERSHIP CENTRE: CO-CREATING SHARED SPACE}

Located on the Westside 5 of Los Angeles, FLC predominantly serves the lowincome, mixed status (i.e. documented and undocumented) Latinx community. This Latinx neighbourhood is relatively unknown and invisible within generalised notions of the Westside. As a community-based organisation, FLC provides various services to help support children, youth, parents and the elderly. FLC works to integrate each community member's desires in creating a healthy and thriving community by sharing in the responsibility of maintaining and generating opportunities. The centre refers to this philosophy as a shared responsibility model. Within weeks of the FLC's opening in the late 70s, the preschool was set ablaze and burned down. Thought to be the work of local gang members, the founders realised that the organisation needed to work cooperatively with the local community. Therefore, the centre adopted a shared responsibility model that works to actively engage and empower every member involved in the programmes offered. This shared responsibility model asks each member to not only participate, but share in the responsibility of sustaining this place. As a guiding framework, FLC reinforces that parental engagement is important in maintaining programmes and supporting their children.

This study focuses primarily on the UYP which serves youth 13-18 years of age. Theyouth programme has many different components that include afterschool tutoring, leadership development, college preparation, parental involvement, mentorship and volunteer opportunities. From 2011-2015 nearly 70-80 youth were enrolled in the programme and primarily supported by two full time staff members overseeing the programme. Most of the youth would be the first-generation in their family to go to college. Many of the youth's parents are gardeners, house cleaners, nannies and stay-at-home parents. Most of the youth enrolled in the UYP identify as Mexican or Mexican American, and Spanish is the primary language spoken at home. From 2011-2015, UYP served

5 There are no formal geographical demarcations that constitute the 'Westside' of Los Angeles. However, the 'Westside' does constitute a geographical imaginary amongst Angelinos. The Los Angeles Times Mapping LA project identifies 23 neighborhoods as constituting the 'Westside'. Some of the more recognisable neighbourhoods include: Santa Monica, Bel Air, Westwood (home to UCLA), Beverly Hills, and Venice. The Westside is one of the wealthiest areas in the greater Los Angeles area. 


\section{SCHOLARLY ENGAGEMENT AND DECOLONISATION}

roughly 65-80 youth each year. Over two-thirds (67\%) of the youth's families met the poverty guidelines ${ }^{6}$ for 2014 . Though more than a quarter of families are above the poverty guidelines, most of the families are low-income with a median income less than $\$ 21,000$ annually. For comparison, the median income of nearby Santa Monica is over $\$ 70,000$ annually. More than $60 \%$ of the youth's mothers' and fathers' highest level of education is middle school or less. FLC provides a shared community space for youth and their families with limited financial means and who confront serious challenges along the educational pipeline.

For many of the participants, the neighbourhood represents a significant challenge in making it to institutions of higher education. One youth described the challenge this way, "I grew up in this community. A lot of people who grow up here, they expect so little of themselves. They don't see themselves going to college, minimum wage jobs or like becoming gardeners. And I think violence and drugs, it keeps them there because if there's violence in our community you feel like you can never get out of here because you know you lived through that". With limited examples and mentors that have gone on to institutions of higher education, getting into college can appear to be even more elusive. However, even as many of the youth recognised gang violence as an issue these experiences were also somewhat normalised. Interviews with youth and former alumni often shared that for part of their life they navigated around the violence and were often cautious and aware of their surroundings. However, even as street violence seemed to be the most consistent way in which youth described their limited opportunities and impediments to college, many of the youth recounted diverse experiences that could also get in the way of their educational goals such as being undocumented, their own or family members' drug and alcohol (ab)use, contentious and uneasy relationships at home, death of a parent and encounters with police.

6 The poverty guidelines are used to determine eligibility requirements for several federal programs. The poverty threshold is set by the Census Bureau and generally determines whether families meet the federal poverty line. However, the poverty threshold considers the number of children under 18 years of age as well as any senior citizens living within the household. Because of the level of detail needed to determine whether a family meets the federal poverty level (i.e. poverty threshold) I used the poverty guidelines. 


\section{COLLEGE CHOICE AND EMPOWERMENT}

Even amongst all of the challenges that these youth face, the UYP programme works hard to provide the opportunities necessary for youth to have the choice to go to college. In the past four years, FLC has been proud of the fact that 100\% of its graduating seniors were accepted into institutions of higher education. I argue that an environment of college choice is informative, enriching and empowering. College choice can be defined as simply providing the most amount of post-secondary options for youth. It consists of not only informing youth about the college-going process, but also of navigating the educational pipeline and providing them with tools that can be used to navigate a multitude of contexts. In the context of UYP, college choice includes providing educationally enriching and supportive services such as STEM classes and afterschool tutoring. Latinx student outcomes at nearby high schools demonstrate that Latinx students lag behind their white counterparts. Based on qualitative interviews, youth recognised that they learned things in UYP that should have been taught in schools. Afterschool tutoring is an important component of ensuring that youth have the option to go to college. Without good grades college options become limited for youth. FLC also created an environment of college choice by leveraging and developing university partnerships. These partnerships provide the opportunity for youth to engage directly with college students. Interactions with college students could be powerful in motivating the youth and making college seem more accessible and attainable. In instances where students could be easily dismissed in their school setting, FLC also provided coaching to help them navigate the educational pipeline. Central to FLC's model is coaching youth to ask for what they want and to consider what they are willing to do to obtain that goal. I argue that this type of coaching reinforces an environment of college choice. FLC also provides workshops to teach youth and their parents about what is needed to get to college and how to pay for it. Research indicates that lack of knowledge and finances can often serve as an impediment to attending and graduating from institutions of higher education. What is unique about what FLC provides in this context, is having youth and parents learn alongside one another. The staff members also help former participants who have interrupted their post-secondary education and are interested in going back to college. All 


\section{SCHOLARLY ENGAGEMENT AND DECOLONISATION}

of these aspects create a college choice environment that is vital for youth so that they recognise that they have agency in navigating their own individual paths post-high school.

STEM and afterschool tutoring are important educational enrichment activities that provide students the space to supplement what they should be learning in schools. Based on data collected by FLC, nearly $60 \%$ of the high school students enrolled in UYP attended two local high schools. With just over 2,000 students enrolled at each of these institutions, Latinx students that met or exceeded standards in language arts, mathematics and science severely lagged behind white students. For example, at one institution, while $61 \%$ of white students met or exceeded expectations in Mathematics, only $31 \%$ of Latinx students met or exceeded standards. At the other institution, while $84 \%$ of white students are proficient or advanced in Science, only $53 \%$ of Latinx students scored proficient or advanced in Science. The educational enrichment arm of the UYP programme provides youth with tutoring, college preparation workshops and STEM courses that last five weeks. FLC has been able to develop and leverage relationships with UCLA and Loyola Marymount University, two nearby universities. Through these partnerships university students often volunteer their time and, in some cases, earned college class credit.

Having a space for youth to do their homework and seek help when necessary is important considering that many of these youth may be struggling in classes. One male respondent shared, "[UYP] helped me a lot so far. The STEM class helped me during tests. Some stuff we didn't even learn about and I'm like oh I know this because of [UYP] because I went to the STEM class". These educational based services not only reinforced what students learned in school, but also supplemented what students should have learned in school. In one youth's reflection they wrote, "the tutoring program really emphasised the importance of school and doing my homework. Not only was it very helpful but it was also a lot of fun. I also like that the tutors were from local colleges because that gave me more motivation to study hard and get grades". For this youth, the value in the tutoring programme was a combination of providing additional support and connecting with college students who serve as role models. Additionally, because FLC provides services to children and youth from preschool to high school, they can support students at different points of the educational system. One youth remarked, "well I noticed a difference 
between the way the classes are run and mainly because of class size because an average class size at Notre Dame is $15-20$ students. Well at my school it's almost 40 students. So like the roughest thing throughout my middle school years is actually getting one-on-one help with my teacher and I never really got that. And I think that's where [FLC] came in and helped me even more throughout middle school". The lack of attention in school is an opportunity for students to fall through the cracks. FLC's tutoring services provide a parachute for students.

College students' interactions with youth provide motivation for youth to attend college. The time that youth spend with college students also provide the opportunity for powerful interactions. During one of my field observations, a local university student was leading a weekly STEM course. Using hands-on techniques the students learned more about blood pressure and diabetes and the ways in which this impacts the Latinx population. Students were asked to share and think deeper about their own knowledge about these chronic diseases. Students' own knowledge was uplifted. Before ending the session, this college student gave a powerful closing. He stated that these youth "gave him motivation to keep going" and he told the youth that they "can do anything they want." This was an especially powerful moment as the youth seemed both gracious and awed by his hope-filled words. The youth clapped enthusiastically for him. This access to role models is a vital component of creating a college-going environment. Connecting youth to college role models makes the idea of college seem less distant and more attainable.

In addition to this, FLC can serve as an advocate on a student's behalf and teach youth how to navigate the educational pipeline. According to the Educational Coordinator, the youth complain about overcrowding of classes, teachers and counsellors that don't seem to care and the lack of resources. The Educational Coordinator coaches the youth to be their own advocates within a school setting. "In the end the student is the one that is going to have the bad grades and affect their college admittance. So I try to coach the students to be their own advocates. Cause then I ask them, well you know they're not giving you homework or ask them what's your grade in your class and they'll say I don't know. I say you should always know what your grade in the class is. Why don't you ask?" In some instances, the youth note that their teacher gets upset with these questions. As a former teacher, FLC's Educational Coordinator 


\section{SCHOLARLY ENGAGEMENT AND DECOLONISATION}

encourages the youth to maintain patience and understanding with teachers who are likely overworked and stressed, though he encourages them to follow up with the teacher and to ask when they can expect to know their grade. If the student is unable to handle this situation, the Educational Coordinator will reach out to school administrators to advocate on the student's behalf. However, this type of coaching empowers youth to advocate first on their own behalf. The Educational Coordinator recognises that the schooling process can be disempowering. Students can become invisible to the teachers, and when the students are asking something from their teacher "it becomes like this sort of power struggle between the student and the teacher". However, advocating on behalf of the student ensures that the student's concerns are not dismissed. "As soon as an outsider, like an advocate from a non-profit organisation joins the conversation then I think there's more trigger of awareness that it's not just the sole student that they're dealing with. It's not just the parent and student they're dealing with. It's the parent, student, and the community they're dealing with so there's more [at] stake." In this system the student is unable to be ignored. This may likely increase the chances that a youth may attend college in the future. By knowing what their grade is, the student takes ownership of their education and is often doing so because they are thinking about future opportunities. The youth are also encouraged to communicate directly with their teacher to find out how they can improve their grade so that it does not diminish their opportunity to go to college.

FLC also provided college and financial aid workshops to the youth and their parents. Some of the youth learn about college requirements through schools or other programmes. However, FLC also ensures that the youths' parents understand the process as well. A former alumnus explained that, as a firstgeneration college student, she was able to discuss college options with her mother because of the workshops that FLC had offered. "That's where I gained a lot of knowledge 'cause I am the first one in my family and we have a big family but I'm the first - I'm one of the first to go to college so I didn't know what was next. I knew I wanted to go but I didn't know how to get there. They were the ones who laid it all out. That is - they sat down with me, did all that, and then my mom also was able to - I was able to have those conversations with her, like should I go here, should I go there 'cause I knew she understood." 
This same alumnus of UYP remembers feeling dismissed upon visiting her own academic counsellor during her junior year. "I had a solid 3.0 and I was in AP courses and I walked up to her. She didn't even look at me. She asked for my name and pulled up my transcript and still not looking at me said 'okay what are you thinking for next year?'" When the student shared that she was interested in attending private universities the alumnus recalls that the counsellor responded, "'well you have a solid 3.0' and I was aware of that and I was like okay I mean I didn't know what was the acceptance GPA or what. I mean to me it was like okay tell me what to do ... she looked up and she was like 'mmm I would aim more for a Cal State.' And to me it was like I'm not asking you what to aim at and I think that because I knew the options that there were from [FLC] ... I never met with her again. She didn't know my work ethic. She didn't know how I wrote essays. You know like all these things that I knew [FLC] would tell us like sometimes 'your grades aren't there but if you can write a good essay that's your key in.” The knowledge that FLC provides about the college-going process provided her with the necessary armour to dismiss the counsellor's disempowering advice.

It is important to recognise that FLC was in the process of shifting towards a college choice environment. I found that in many respects FLC's definition of empowerment was strongly tied to education, though the educational coordinator recognised that they were shifting to reinforce the choice to go to college. "Our narrative has sort of changed from saying we want all of you to go to college to say that we want all of you to have the option to go to college." However, even as a college-going environment is important, placing too much emphasis on college can also diminish alternative trajectories. A college choice framework is important because it recognises the agency of youth who may choose to take a different path. While research indicates that Latinx students are overrepresented at the community college level and face challenges in finishing their degree, working from this fear can also be detrimental and disempowering. A former alumnus recalls that FLC's former Education Coordinator had encouraged her to apply to schools within the California State University system. Although she had been accepted into several of them, she decided to attend a local community college. She recalls: "And I told him I was like I'm going to go to [community college] and then I'm going to transfer ... and he's like 'are you serious why are you doing that? Come on you'll 


\section{SCHOLARLY ENGAGEMENT AND DECOLONISATION}

do great in a four year' and he didn't really give me a chance to explain. And he said 'ugh, you're just going to be there for five years and not get out.' Cause a lot of other members had been there 5/6 years and nothing was coming out of it ... But now I see it as in he wanted me to do better and wanted me to have it all and maybe he thought I was lowballing myself." This comment reinforces the key differences between a college-going and college choice environment. Although this former alumnus took this as motivation to prove him wrong, she felt that these types of comments could be dangerous in reinforcing the belief in youth that they won't make it through institutions of higher education. A college-going environment does not necessarily recognise the agency of youth in choosing alternative plans after high school.

\section{LEADING THE YOUNGSTERS}

Some of the most powerful experiences youth had while participating in FLC's programmes were opportunities to lead younger children. These opportunities are important moments in which the youth have the opportunity to demonstrate their own power. In the context of empowerment discussions, these are moments in which students recognise their own value. Being a role model to younger youth may encourage youth to continue onto institutions of higher education. It reinforces what youth have to offer and provides an alternative to a subtractive schooling system.

UYP youth have the opportunity to tutor younger students, help lead and facilitate a pre-teen programme, or serve as counsellors (or counsellors in training) in the organisation's summer camp. An analysis of written reflections indicates that participating in the summer camp as a leader is one of the most important leadership opportunities. In preparation for this, FLC trains its youth on how to work with children. Some of the youth reflections revealed that they learned that telling children what to do wasn't enough to get them to accomplish a goal. The youth had to learn how to motivate their summer camp group. It also provides the youth with the opportunity to pull back the curtain and to understand on a deeper level the amount of work it takes to put this summer camp together. As previous participants, some of the youth deepened in their gratitude of their own summer camp experiences. One of the youth reflections stated, "I felt as if I had more responsibilities. I had to set an example for the little kids because some [of] them looked up to me and I would 
like to leave a good impression”. In some cases, this experience encouraged youth to consider a career in child development. Envisioning a future self is a powerful experience that may further develop a curiosity and consciousness of what it will take to reach these future career goals.

David, one of the youths, stated that serving as a role model helped him decide to be a better person. David recognises that a few years back he was acting out in school and regularly getting into fights with teachers. He admits that he enjoyed the attention and that "getting in trouble wasn't a problem for me". During his $8^{\text {th }}$ grade, David became upset with one of his teachers, and he and a couple of other students vandalised and stole from a classroom. When David was caught, he was required to do community service hours. Because of his involvement with FLC, he began working with the younger youth. David describes this as a turning point in which working with the younger youth helped him decide to become a better person. "I found myself having a good time and like when I started helping out with little kids and showing them things and teaching them things you know, then that's when I really decided this is the type of person I want to be. This is who I want to be and what I want to do." This experience provided David with the opportunity to see the value in his own talents and gain recognition for doing something good. However, it is important to note that without FLC, David could have completed his community service hours in ways that might not have led to such an enriching experience. While Latinx youth are sometimes viewed through a prism of deficiency, this experience demonstrates the importance of recognising youth. David marks this decision as a turning point in how he approached school. In the $9^{\text {th }}$ grade, he describes making a concerted effort to raise his grades in part because he began to think more seriously about the possibility of going to college.

\section{PUTTING IN OVERTIME FOR FREE}

In considering the supportive environment that FLC generates, I think it is important to acknowledge the challenges that it faces as an organisation in this intermediary role. The primary challenge that staff were most concerned about was financial constraints that limited the types of opportunities that the programme could provide for youth. Funding challenges restrict the centre's ability to hire additional workers. In the midst of this, staff members seemed 


\section{SCHOLARLY ENGAGEMENT AND DECOLONISATION}

to be doing the work of two or three additional people. Funding challenges are not only unique to FLC, but a recurring challenge for non-profits in general (Marwell, 2004; Hasenfeld, Hyeon, Chen \& Parent, 2012; Hasenfeld, Chen, Garrow \& Parent, 2013, Ong, et al., 2014). Funding shortages not only threaten the organisation's survivability, but also threaten to exacerbate the already precarious environment of the families and community they serve. Lack of funding can threaten to cut off the college choice path that the organisation has tirelessly worked for.

Staff reported experiencing salary cuts and simultaneously being given more responsibilities, feeling stretched too thin, and overtaxed in terms of the need to prove the effectiveness of their work to foundations. Some staff members expressed a sense of disempowerment when they described the pressure to quantify their work to foundations or the organisation's Board of Directors. Because of inconsistent funding, FLC has lowered staff salaries. On several occasions, the staff took pay cuts and even volunteered their time just to keep the centre open for the youth and their families.

Since President Johnson's War on Poverty initiatives in the 1960s, the US governmenthasincreasingly funnelled money to a third sector of organisations. This shifts the responsibility of providing a public safety net away from the federal government (Marwell, 2004). Privatisation and devolution in the 1970s and 1980s increased the needs of families and individuals struggling. Nonprofits have increasingly taken on the role of serving these struggling families. Today, the human services sector is increasingly privatised, and services are increasingly provided directly by private for-profits and non-profit entities that apply for government contracts (Mulroy, 2004). These shifts in public policy not only increase the precarity of already struggling communities, but they increasingly shift the blame and responsibility to non-profits to serve the multitude of needs that the government fails to meet.

Non-profits are often constantly concerned with financial uncertainty, which can be due to a confluence of factors including economic downturns, decreased federal funding, private foundation interests and expectations. Increased financial uncertainty greatly contributes to a much more fragile environment for non-profits. The UCLA Center for Civil Society (CCS) has produced several reports that shed light on the increasing precariousness that non-profits must contend with. Following the most recent national economic 
downturn CCS concluded that the "Los Angeles human services non-profit sectors is stressed and stretched ... since the recession began, the sector has seen a dramatic increase in hiring and salary freezes, furlough programs, layoffs, and increased reliance on volunteers. In small organizations, the loss of just one person, who often does multiple duties, can be crippling" (Hesenfeld et al., 2012:vi-vii). Even after the recession, individual giving in Los Angeles is less than what it was before the recession occurred. Ong et al. (2014:4) argue that the "individual giving patterns reflect growing inequality ... many of the wealthy appear to be making more and giving less".

Interviews with FLC staff members, for example, reveal that while foundations may be willing to fund a programme, they often restrict funding so that grant dollars cannot be used to pay for staff salaries to run these programmes. As foundations seek to influence public policy, they have been known to change their area of focus, shifting funding and closing vital funding streams to organisations such as FLC. From the perspectives of non-profits, funders "preoccupation with innovation promotes mission drift and undermines the work at hand” (Hesenfeld et al., 2013:23). Interviews with FLC confirm that this has also been their experience:

The need for our organization is to reinforce and reinvest in the programs that we already have because of the need for funding we've been sort of stretching ourselves out thin looking for other kinds of funding that we, for programs that we have not even established yet. But because there is an interest in funding that we establish out of nowhere a program to be able to cater to this funding requirement or whatever. So that's when you have different staff members taking on more responsibilities. Writing more reports and still getting paid the same and still with the constant threat that our salaries can go further down at any moment. Um, I guess that's just the nature of the beast when you talk about non-profits. That uh especially a non-profit like ours that's funding $100 \%$ by private funders that um it almost seems that any moment our funding can be taken away. And so then we have to scramble to look for different modes of funding. Um just to keep our doors open to keep our salaries intact. So that's been tough to deal with.

Many of the staff members who come from similar backgrounds as the youth also worry about their own precarious situation as their staff salaries have been cut. Though one might analyse the staff member's remarks as a failure of the organisation, these decisions are strategies of survival. That is, FLC and 


\section{SCHOLARLY ENGAGEMENT AND DECOLONISATION}

non-profits like it are already operating within a complex multi-layered system that often fails to meet the needs of low-income, Latinx mixed status families. Even in the midst of this, staff members have volunteered (i.e. without pay) their time to keep the centre open for the youth and the centre's families. The lack of or cutting off of funding streams threatens not only the organisation, but the entire community. As a vital resource it is important to consider what is needed for non-profits to continue their work of supporting youth's dreams of college.

\section{CONCLUSION}

This study has examined the ways in which one non-profit, the FLC, has worked to create a college choice environment. Using a case study method, this chapter has revealed the barriers that impede Latinx youth visions of higher education and how FLC works to diminish these barriers. Many of these youth come from low-income mixed status families and are often the first in their families to go to college. The opportunities that FLC provides demonstrates the importance of a college choice environment in recognising the agency that youth maintain. It also considers the importance of youth being given the opportunity to serve as role models as a powerful motivator that may help create resiliency once in college. Lastly, this chapter considers the financial constraints that FLC faces. Financial constraints are not unique to FLC and are well-known challenges that non-profits constantly maneuver. However, as demonstrated in this chapter, it is important not only to consider how organisations do the work they do, but the challenges they face that threaten to further get in the way of Latinx youth entrance into institutions of higher education. 


\section{CHAPTER 13 College choice}

\section{REFERENCES}

Abrego, L.J. 2014. Sacrificing Families: Navigating Laws, Labor and Love Across Borders. Stanford: Stanford University Press.

Baldassare, M. 2000. California's MajorityMinority Milestone: What Lies Ahead? Public Policy Institute of California. Available: http://bit.ly/2Uo981V [accessed 6 June 2016].

Bronfenbrenner, U. 1979. The Ecology of Human Development. Cambridge: Harvard University Press.

Burciaga, R.; Pérez Huber, L. \& Solórzano, D.C. 2010. Going Back to the Headwaters: Examining Latina/o Educational Attainment and Achievement Through a Framework of Hope. In: E.G. Murillo, S.A. Villenas, R.T. Galván, J.S. Muñoz, C. Martínez \& M. Machado-Casas (eds.), Handbook of Latinos and Education: Theory, Research, and Practice. New York: Routledge. pp.422-437.

California Department of Education. 2016. 2005-2006 APR Glossary-API Growth. Available: http://bit.ly/2RZ381n [accessed 1 June 2016].

California Senate Office of Research. 2017. A Statistical Picture of Latinos in California, 2017 Update. Prepared for the Latino Legislative Caucus.

De Genova, N. 2009. Working the Boundaries. Durham: Duke University Press.
De Genova, N. 2010. The Deportation Regime: Sovereignty, Space and the Freedom of Movement. In: N. De Genova, \& N. Puetz (eds.), The Deportation Regime: Sovereignty, Space, and the Freedom of Movement. Durham: Duke University Press. pp.33-65. https://doi. org/10.1215/9780822391340-002

De La Cruz-Viesca, M.; Chen, Z.; Ong, P.M.; Hamilton, D. \& Darity, W.A. 2016. The Color of Wealth in Los Angeles. San Francisco: Federal Reserve Bank of San Francisco.

Eccles, J. \& Gootman, J.A. (eds.). 2001. Community programs to promote youth development. Washington, DC: National Academy Press.

Flores, S.M. 2010. Assessing the Higher Education Opportunity Structure for Latino Students. In: E.G. Murillo, S.A. Villenas, R.T. Galván, J.S. Muñoz, C. Martínez \& M. Machado-Casas (eds.), Handbook of Latinos and Education: Theory, Research, and Practice. New York: Routledge. pp.210-218.

Flyvbjerg, B. 2006. Five Misunderstandings About Case-Study Research. Qualitative Inquiry, 12(2):219-245. https://doi. org/10.1177/1077800405284363

Freeman, J., Kim, D. \& Rawson, Z. 2013. Black, Brown, and Over-Policed in L.A. Schools: Structural Proposals to End the School to Prison Pipeline in the Los Angeles Unified School District and to Build a National Movement to Stop the Mass Incarceration of Black and Latino communities. Los Angeles: Community Rights Campaign of the Labor/ Community Strategy Center. 


\section{SCHOLARLY ENGAGEMENT AND DECOLONISATION}

Gonzales, A. 2014. Reform without justice: Latino migrant politics and the homeland security state. New York: Oxford University Press. https://doi.org/10.1093/acprof:o so/9780199973392.001.0001

Gramlich, J. 2017. Hispanic dropout rate historic new low, college enrollment at new high. Washington, DC:

Pew Research Center.

Hammersley M \& Gomm R. 2000. Introduction. In: R. Gomm, M. Hammersley \& P. Foster (eds.), Case Study Method: Key Issues, Key Texts. Thousand Oaks, CA: SAGE Publications. pp.1-16.

Hasenfeld, Z.; Chen, M.; Garrow, E. \& Parent, B. 2013. Spread Thin: Human Services Organizations in Poor Neighborhoods. Available: http://bit. ly/2UoWL9l [accessed 6 June 2016].

Hasenfeld, Z.; Hyeon, J.K.; Chen, M. \& Parent, B. 2012. Stressed and Stretched: The Recession, Poverty, and Human Services Nonprofits in Los Angeles, 2002-2012. Available: http://bit. ly/37ZdXG7 [accessed 8 July 2016].

Holland, G. 2014. Los Angeles is among the top 10 U.S. cities for income inequality. Los Angeles Times. Available: https://lat. ms/2tycAzu [accessed 11 October 2015].

HoSang, D.M.; LaBennet, O. \& Pulido, L. (eds.). 2012. Racial Formation in the Twenty-First Century. Berkeley: University of California Press. https://doi.org/10.1525/ california/9780520273436.001.0001

INCITE! Women of Color Against Violence (ed.). 2010. The Revolution Will Not Be Funded: Beyond the NonProfit Industrial Complex. Durham: Duke University Press.
Kaiser Family Foundation. 2017. Poverty by Race/Ethnicity. Available: http://bit. ly/2uaOXPA [accessed 26 February 2018].

Kim, C.Y.; Losen, D.J.; \& Hewitt. D.T. 2010. The School-to-Prison Pipeline: Structuring Legal Reform. New York: New York University Press.

Kwon, S.A. 2006. Youth of Color Organizing for Juvenile Justice. In: P. Noguera, J. Cammarota \& S. Ginwright (eds.), Beyond Resistance! Youth Activism and Community Change. New York: Routledge. pp.215-228.

Lipsitz, G. 1998. The Possessive Investment in Whiteness. Philadelphia: Temple University Press.

Lipsitz, G. 2011. How racism takes place. Philadelphia: Temple University Press.

Lopez, M.H. 2009. Latinos and Education: Explaining the Attainment Gap. Washington, DC: Pew Hispanic Center.

Lopez, M.H.; Gonzalez-Barrera, A.; Krogstad, J.M. \& López, G. 2016. Democrats Maintain Edge as Party 'More Concerned' for Latinos, But Views Similar to 2012. Available: https:// pewrsr.ch/398dC4k [accessed 27 August 2018].

Marwell, N.P. 2004. Privatizing the Welfare State: Nonprofit CommunityBased Organizations as Political Actors. American Sociological Review, 69:265-291. https://doi. org/10.1177/000312240406900206

Menjívar, C. 2006. Liminal Legality: Salvadoran and Guatemalan Immigrants' Lives in the United States. American Journal of Sociology, 111(4):999-1037. https://doi. org/10.1086/499509 


\section{CHAPTER 13 College choice}

Menjívar, C. \& Abrego, L.J. 2012. Legal Violence: Immigration Law and the Lives of Central American Immigrants. American Journal of Sociology, 117(5):1380-1421. https://doi. org/10.1086/663575

Molina, N. 2013. Examining Chicana/o History through a Relational Lens. Pacific Historical Review, 82(4):520-541. https://doi.org/10.1525/phr.2013.82.4.520

Moll, L.C.; Amanti, C.; Neff, D. \& González, N. 1992. Funds of knowledge for teaching: Using a qualitative approach to connect homes and classrooms. Theory Into Practice, 31(2):132-141. https://doi. org/10.1080/00405849209543534

Mosley, J.E.; Maronick, M.P. \& Katz, H. 2012. How Organizational Characteristics Affect the Adaptive Tactics Used by Human Service Nonprofit Managers Confronting Financial Uncertainty. Nonprofit Management \& Leadership, 22(3):281-303. https://doi.org/10.1002/ $\mathrm{nml} .20055$

Mulroy, E.A. 2004. Theoretical Perspectives on the Social Environment to Guide Management and Community Practice. Administration in Social Work, 28(1):77-96. https://doi.org/10.1300/ J147v28n01_06

Muñiz, A. 2015. Police, power, and the production of racial boundaries. New Brunswick, NJ: Rutgers University Press.

Muñiz, A. \& McGill, K. 2012. Tracked and Trapped: Youth of Color, Gang Databases and Gang Injunctions. Youth Justice Coalition. Available: http://bit. ly/31muD8e [accessed 27 March 2014].
Negrón-Gonzales, G. 2014. Undocumented, unafraid and unapologetic: Rearticulatory practices and migrant youth "illegality." Latino Studies, 12:259-278. https://doi.org/10.1057/1st.2014.20

Noguera, P.A. 2003. Schools, Prisons, and Social Implications of Punishment: Rethinking Disciplinary Practices. Theory into Practice, 42(4):341-350. https://doi.org/10.1207/ s15430421tip4204_12

Ochoa, G. 2013. Academic Profiling: Latinos, Asian Americans, and the Achievement Gap. Minneapolis: University of Minnesota Press. https://doi.org/10.5749/ minnesota/9780816687398.001.0001

Omi, M. \& Winant, H. 2015. Racial formation in the United States. Third Edition. New York: Routledge.

Ong, P., Jimenez, S., Parent, B. \& Ong, E. 2014. The State of Donations Individual Charitable Giving in Los Angeles. Available: http://bit.ly/2v2Y3fz [accessed 1 June 2015].

Pérez Huber, L.; Malagón, M.C.; Ramirez, B.R.; Camargo Gonzalez, L.; Jimenez, A. \& Vélez, V.N. 2015. Still Falling Through the Cracks: Revisiting the Latina/o Education Pipeline. CSRC Research Report. Los Angeles: UCLA Chicano Studies Research Center.

Pérez Huber, L.; Vélez, V.N. \& Solórzano, D.G. 2014. The Growing Educational Equity Gap for California's Latina/o Students. Latino Policy \& Issues Brief. Los Angeles: UCLA Chicano Studies Research Center. 


\section{SCHOLARLY ENGAGEMENT AND DECOLONISATION}

Peutz, N. \& De Genova, N. 2010. Introduction. In: N. De Genova \& N. Peutz (eds.), The Deportation Regime: Sovereignty, Space, and the Freedom of Movement. Durham: Duke University Press. pp.1-29. https://doi. org/10.1215/9780822391340

Ramirez, T.L. \& Blay, Z. 2016. Why People Are Using the Term 'Latinx.' HuffPost. Available: http://bit.ly/36S1qDa [accessed 1 September 2018].

Rios, V. 2011. Punished: Policing the Lives of Black and Latino Boys. New York: New York University Press.

Salinas, C. \& Lozano, A. 2017. Mapping and recontextualizing the evolution of the term Latinx: An environmental scanning in higher education. Journal of Latinos and Education, 1(14). https://doi.org/10.1 080/15348431.2017.1390464

San Miguel, G. \& Donato, R. 2010. Latino Education in Twentieth-Century America: A Brief History. In: E.G. Murillo, R.T. Galván, J.S. Muñoz, C. Martínez \& M. Machado-Casas (eds.), Handbook of Latinos and Education: Theory, Research, and Practice. New York: Routledge. pp.27-62.

Shipler, D.K. 2005. The Working Poor: Invisible in America. New York: Vintage Books.

Smith, A. 2010. Introduction: The Revolution Will Not Be Funded. In: INCITE! Women of Color Against Violence (ed.), The Revolution Will Not Be Funded: Beyond the Non-Profit Industrial Complex. Durham: Duke University Press. pp.1-18.
Sólorzano, D.G.; Villalpando, O. \& Oseguera, L. 2005. Educational Inequities and Latina/o Undergraduate Students in the United States: A Critical Race Analysis of Their Educational Progress. Journal of Hispanic Higher Education, 4(3):272-294. https://doi. org/10.1177/1538192705276550

Terriquez, V. \& Kwon, H. 2014. Intergenerational Family Relations, Civic Organisations, and the Political Socialisation of Second-Generation Immigrant Youth. Journal of Ethnic and Migration Studies, 41(3):425-447. https://doi.org/10.1080/136918 3X.2014.921567

UCLA Center for Labor Research and Education. 2008. Underground Undergrads. In: G. Madera, A.A. Matha, A.M. Najafi, H.H. Saldívar, S. Solis, A.J.M Titong, G. Rivera-Salgado, J. Shadduck-Hernández, K. Wong, R. Frazier \& J. Monroe (eds.). Los Angeles: UCLA Center for Labor Research and Education.

U.S. Census Bureau. 2016. QuickFactsCalifornia. Available: http://bit. ly/3balbta [accessed 15 December 2017].

U.S. Census Bureau. 2013. Selected Social Characteristics in the United States, 2009-2013 American Community Survey 5-Year Estimates. Available: http://bit.ly/31qshoO [accessed 18 June 2015].

Valenzuela, A. 1999. Subtractive Schooling: U.S.-Mexican Youth and the Politics of Caring. Albany: State University of New York Press. 


\section{CHAPTER 13 College choice}

Valle, V.M. \& Torres, R.D. 2000. Latino Metropolis. Minneapolis: University of Minnesota Press.

Wald, J. \& Losen, D.J. 2003. Defining and redirecting a school-to-prison pipeline. New Directions for Youth Development, 99:9-15. https://doi.org/10.1002/yd.51

Wong, T.K. 2015. Rights, Deportation, and Detention in the Age of Immigration Control. Stanford: Stanford University Press. https://doi.org/10.11126/ stanford/9780804793063.001.0001
Yin RK. 2009. Case Study Research: Design and Methods. Fourth Edition. Thousand Oaks: SAGE Publications.

Youth Justice Coalition. 2013a. Negative Impacts of Gang Injunctions on Youth and Communities. Available: http://bit.ly/2OsEaFp [accessed 11 November 2014].

Youth Justice Coalition. 2013b. Echo Park Gang Injunction. Available: http://bit. ly/36S21Vq [accessed 11 November 2014]. 